\title{
When your child needs a blood transfusion
}

Note to Physicians:

This information is a tool to help treating physicians obtain informed consent for blood transfusions from patients, parents or their guardians. It is adapted from a document by the Children's Hospital of Eastern Ontario. The Canadian Paediatric Society thanks them for sharing their material. Quantitative risk estimates in this document must be updated as new information appears in the literature. Individual institutions may modify this document to better suit local circumstances.

Yos our child may need a blood or blood product transfusion during a major surgery or to treat a medical condition. This handout will help you understand the different parts of blood that are often used, along with the benefits and risks of having a transfusion. A doctor or nurse will be happy to discuss your child's situation, and answer your questions.

\section{WHAT IS A TRANSFUSION?}

Human blood can be used to make more than 30 different products. Putting these blood products into someone's body is called a transfusion. The blood product is usually given through a small needle placed into a vein.

\section{WHY WOULD A PATIENT NEED A TRANSFUSION?}

A transfusion can help a patient recover from a serious illness, surgery or injury. Sometimes, patients need repeated transfusions because they are missing important parts of blood.

\section{WHAT PARTS OF THE BLOOD ARE USED MOST OFTEN?}

Sometimes, during one hospital stay, a patient may need several transfusions of different blood products. Most transfusions involve red blood cells, platelets, plasma or plasma products.

\section{WHAT DO THESE PARTS DO?}

Red blood cells carry oxygen to all tissues in the body so that they stay alive and work well. If there has been a lot of bleeding, a patient may need a red blood cell transfusion. This helps get oxygen to tissues and prevents more damage.

Platelets are cells that help prevent and stop bleeding.

Plasma is the yellow liquid that surrounds the red blood cells and platelets. Plasma is used most often to help blood clot. It may be used with platelets to prevent or stop bleeding. Other products can be made from plasma. Some of these can be used to treat special bleeding problems such as hemophilia.
Plasma is also used to make products called immunoglobulin preparations that help the body fight infection and treat medical conditions. Some of the diseases that can be helped with these plasma products are idiopathic thrombocytopenic purpura (also known as ITP, a disease that causes low platelets and bleeding) and Kawasaki disease (which causes a high fever, skin rash, aches and pain and, sometimes, damages the blood vessels of the heart).

Other blood products are used in very specific cases. If your child needs them, your doctor will discuss them with you in detail.

\section{WHERE DOES DONATED BLOOD COME FROM?}

Canadian Blood Services and Héma-Québec collect blood from volunteer donors. Before it is used, blood is tested and divided into separate parts or units. If your child needs a transfusion, he or she will be given just the part that is needed.

\section{ARE THERE RISKS TO HAVING A BLOOD TRANSFUSION?}

There are several possible problems from a blood transfusion.

- Allergic reactions. These include rashes and hives. They are usually mild and easily treated. Severe allergic reactions are rare.

- Fever reactions. A fever usually means a patient's body is reacting to white blood cells or plasma proteins from the donor's blood. The fever is usually not severe, and can be treated easily. If your child has had a bad fever in the past, after or while receiving a transfusion, you should talk to his or her doctor. Most fevers can be prevented.

- Infectious disease transmission. Every effort is made to ensure that the blood your child receives is safe. Donors are interviewed to make sure they are healthy, and then every unit of blood is tested. But even with this system, there is still a small risk of

All material presented in Paediatric Infectious Disease Notes has been reviewed by the Canadian Paediatric Society Board of Directors Department of Pediatrics, IWK-Grace Health Centre, Halifax, Nova Scotia

Correspondence: Infectious Diseases and Immunization Committee, Canadian Paediatric Society, 2204 Walkley Road, Suite 100, Ottawa, Ontario K1G 4G8. Telephone 613-526-9397, fax 613-526-3332, web site www.cps.ca 
catching a disease from donated blood. It is possible for a donor to have a virus and not seem sick, and the tests are not $100 \%$ perfect.

- Incompatible blood grouping. Sometimes, the cells of the donor react with the cells in the recipient's body because they are a different type. To make sure this doesn't happen, the lab will carefully check your child's red blood cell grouping (A, B, O and $\mathrm{Rh}$ ), and choose a unit that matches.

\section{WHAT ARE THE CHANCES MY CHILD WILL GET A CONTAGIOUS DISEASE?}

Because blood donors are screened and their blood is tested, blood transfusions are very safe. The risks of getting diseases such as HIV, hepatitis B and hepatitis C are very small. The risk of HIV infection has been reduced to less than 1 in 913,000 units in Canada. Hepatitis B and C viruses are also routinely tested for and, according to data from the United States, the risks of these infections are now extremely low, as well. The risk of hepatitis B from transfusion is 1 in 63,000 units. The risk of getting hepatitis $\mathrm{C}$ is even smaller, now that a new test can find the virus right in the blood. The risk is now 1 in 103,000 units. Although blood can never be $100 \%$ safe, the risk of infection from transfusion is very low. For products made from plasma (such as albumin and immunoglobulin), additional steps eliminate any of the viruses mentioned above that may remain after testing.

You may have heard about Creutzfeldt-Jakob disease. Some people say that it may be passed on by blood transfusion. But this has not been proven. There are no known cases of this disease that have been passed on by blood transfusion. If you have questions about this disease or any others, please feel free to discuss them with your child's doctor.

\section{DOES MY CHILD HAVE TO RECEIVE A STRANGER'S BLOOD?}

Not necessarily. Here are two other options.

- Autologous blood donation. This means that the patient donates his or her own blood before surgery. This has been done safely with children, elderly people, pregnant women and even people with heart disease. But donating one's own blood is NOT an option for everyone, especially very small children. You will need to talk with your child's doctor to find out if this option is possible.

If your child donates his or her own blood and it is not used, it is discarded after 35 days. It is NOT used for anyone else.

To donate your child's own blood, your child's doctor must fill out a request form that is sent to Canadian Blood Services or Héma-Québec. A nurse will contact you to make the arrangements. Your child can only make one donation per week, and only until one full week before surgery.

- Directed donations. Sometimes, parents can donate blood to be used only for their child. Ask your doctor about this.

There may be other alternatives such as the use of saline or nonplasma-derived clotting factor concentrates made by new DNA technology or other manufactured products. There are also procedures, such as blood salvaging, that may be an option for your child. It is important to discuss the details with your child's doctor.

\section{WHAT IF I DECIDE NOT TO ALLOW MY CHILD TO HAVE A TRANSFUSION?}

Accidents or surgery can cause heavy or uncontrollable bleeding. A transfusion can save a life or prevent serious complications. If blood is not replaced, the patient may go into shock, lack oxygen or even die. If platelet counts are very low, the patient will bleed too much and bruise. Without a platelet transfusion, there can be bleeding inside the body. There can also be massive bleeding, especially in the head. Your child may need other blood products (such as albumin, gamma globulin and clotting factors) for special purposes, either to fight or to prevent infection, immune system reactions and bleeding. Without these products, the infection and bleeding may get worse or become impossible to control.

\section{HOW DO I DECIDE ABOUT A TRANSFUSION?}

Your doctor or an assistant will explain why a transfusion is needed, along with the risks and benefits, as long as there is enough time. This is called the informed process. To use your child's blood or your blood, you will have to speak with your doctor. You will have to sign an informed consent form.

\section{IS INFORMED CONSENT NECESSARY?}

Yes, in situations that are not life-threatening, patients or their parents or guardians need to understand why a transfusion is recommended, and the benefits and risks. By providing you with this information handout and the chance to discuss it with your doctor, you should be able to give your 'informed consent' for this procedure to go ahead. Sometimes an urgent transfusion may be needed in a life-threatening situation. In these cases, it will not be possible to get informed consent in advance.

\section{SHOULD A BLOOD TRANSFUSION RECORD BE KEPT?}

Yes. Before you leave the hospital, make sure you receive something in writing that says your child received blood or blood products. This is important medical information that should be kept with your child's medical file for future reference.

This article also appears in Paediatr Child Health 2000;5(5):291-294. 


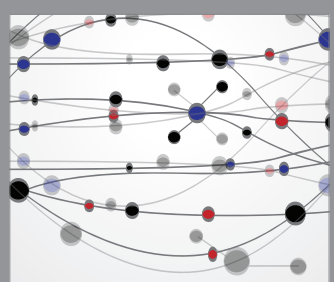

The Scientific World Journal
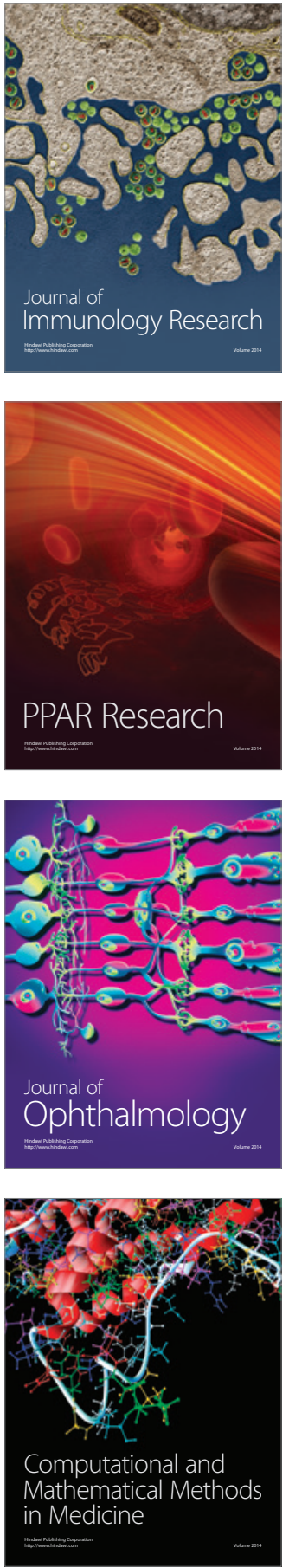

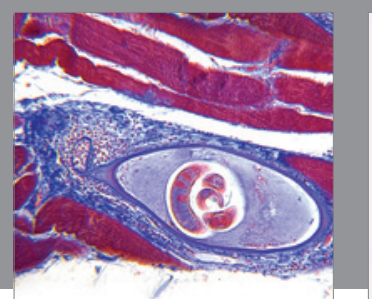

Gastroenterology Research and Practice

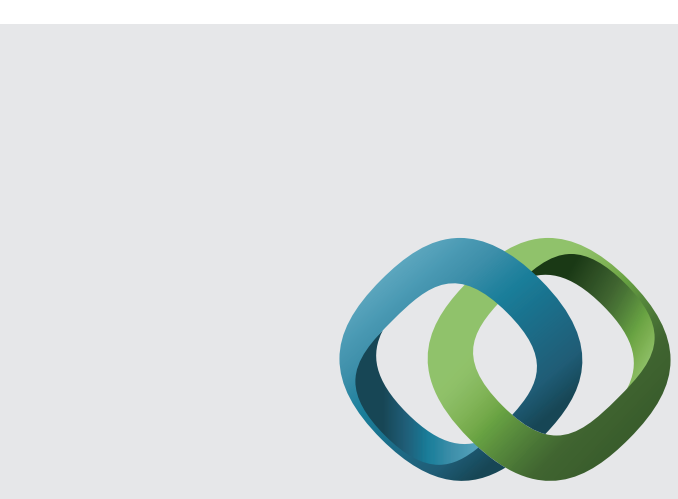

\section{Hindawi}

Submit your manuscripts at

http://www.hindawi.com
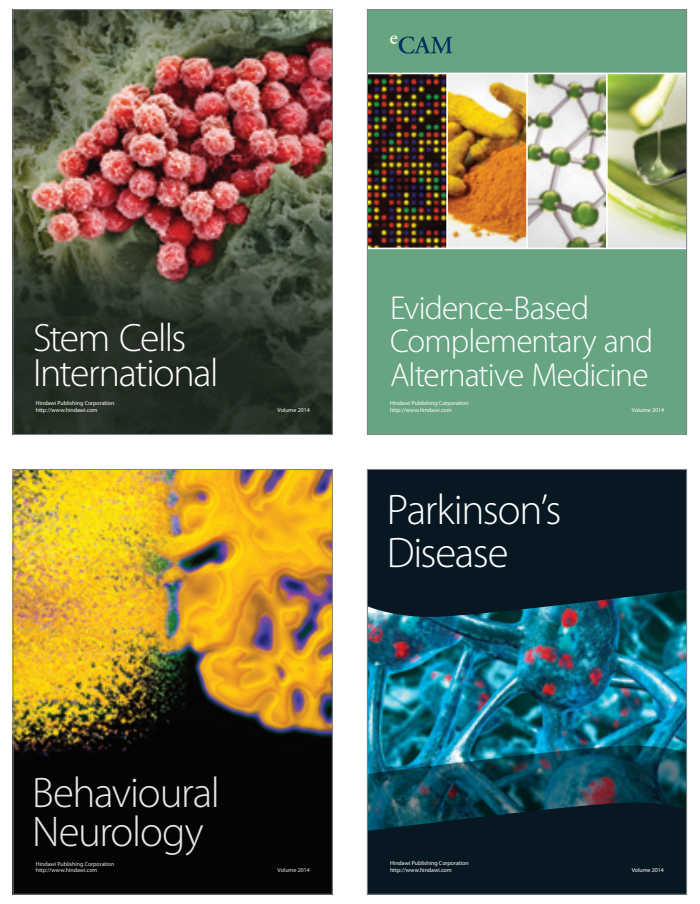
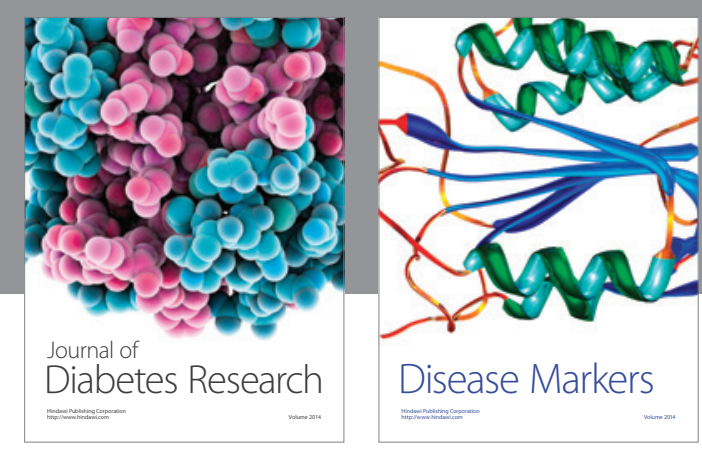

Disease Markers
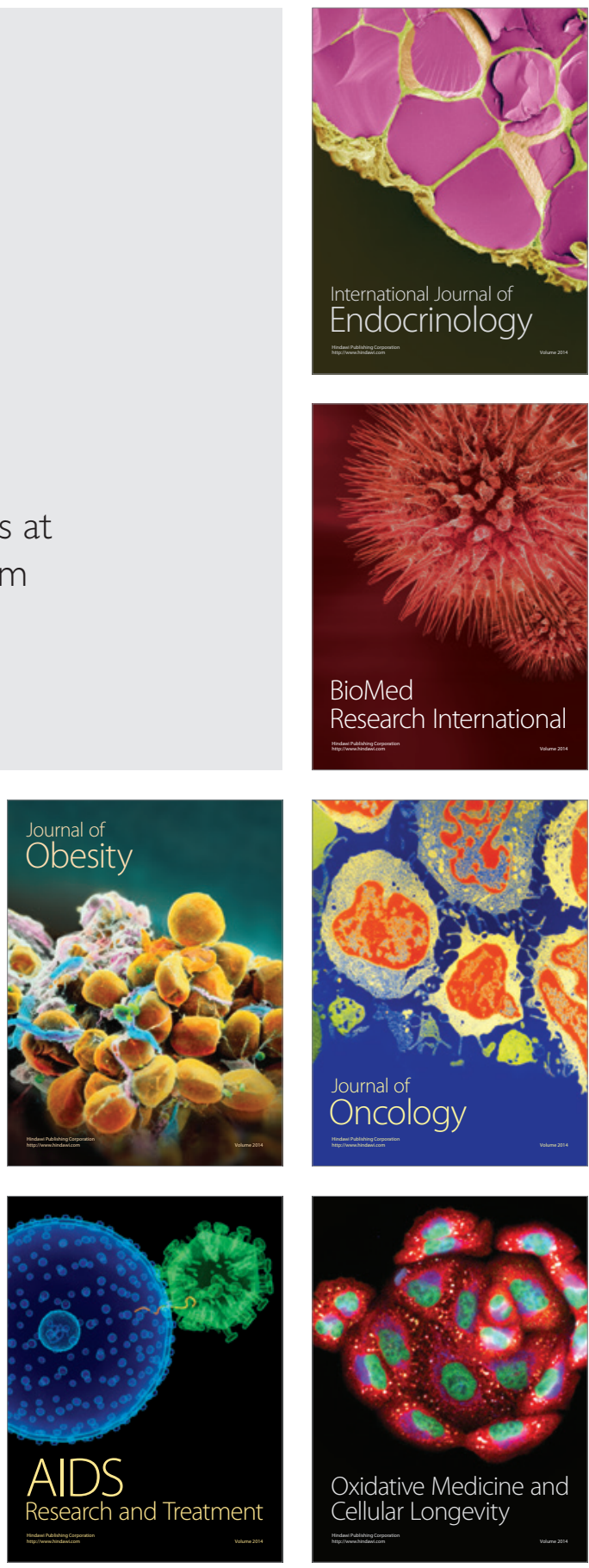